Tér és Társadalom 8. $1994 \square 1-2: 235-243$

\title{
KÖNYVJELZÖ
}

\section{A FINN NEMZETI VIDÉKPOLITIKA AZ EURÓPAI INTEGRÁCIÓ KIHÍVÁSA ELÖTT}

\author{
P. Malinen- H. Jussila-M. Häkkilä (1993) Finland's National Rural Policy \\ facing the Challenge of European Integration \\ University of Oulu Research Institute of Northern Finland
}

Research Reports 114. Oulu

Ez a könyv egyike azoknak a kiadványoknak, amelyeket a finnek angol nyelven jelentettek meg abból a célból, hogy az Európai Unió minél jobban megismerje és méltányolja a finn mezôgazdaság és vidék sajátos problémáit. A könyv számtalan más, napjainkban megjelenó angol nyelvũ kiadvánnyal együtt egyfajta lobbizás a finn mezốgazdaság féltett jövôjéért.

A finnek az Európai Unióhoz való csatlakozásuk (amely felốl a többségnek nem voltak kétségei) kapcsán tele voltak aggályokkal. Különösen vonatkozott ez a mezógazdaságból élốkre. Pár hónappal az integrációról szóló népszavazás elốtt a farmerek 70\%-a ellenezte és csak 30\%-a értett egyet a csatlakozással. A mezógazdasággal és a vidékpolitikával foglalkozó kutatók - a maguk intellektuális eszközeivel - mindent megtesznek annak érdekében, hogy a farmerek a lehetố legkisebb megrázkódtatások árán éljék át a szükséges változást és az új alkalmazkodási kényszert.
A szerzök a könyvben a finn vidék és a vidékpolitika történelmi és regionális sajátosságai bemutatásával foglalkoznak. Finnország múltjában és jelenében az egész gazdaság szempontjából meghatározó az erdó, a fafeldolgozás. Ma az ország $85 \%$-át erdó borítja. Ezt, továbbá az éghajlati viszonyokat figyelembe véve, kiváló teljesítménynek mondható, hogy a finn mezõgazdaság már az 1950-es években elérte a lakosság élelmiszerszükségletének kielégítését. Az 1960-as évek közepéig a farmok száma és a falusi lakosság folyamatosan nốtt. A regionális politika fố célja az elegendố élelmiszer biztosítása volt. Amikor ezt a célt a finn parasztok ,túlteljesítették", akkor sok minden megváltozott a társadalomban, így például csökkentek a támogatások - amelyek elsősorban a szarvasmarha-tenyésztést és tejtermelést segítették -, továbbá az erdei munkákat, fôleg a fakitermelést gépesítették, amiáltal a falvakban munkaerôfelesleg keletkezett. A lakosság egyre jobban fel- 
hagyott a mezõgazdasági termeléssel és az ipari városok agglomerációs övezeteiben telepedett le. Ez volt a ,,nagy migráció", amely Észak- és Kelet-Finnországból Délnyugat-Finnországba vezetett, és amely az egyébként is gyéren lakott ország további területeinek elnéptelenedését eredményezte. Úgy tûnt, hogy a társadalomban a vidéki térségek problémái háttérbe szorultak, de hogy ez mégse következzen be, megszületett a vidékpolitika, amely a vidéki foglalkoztatásban a diverzifikációt jelölte meg célként és rendkívül nagy hangsúlyt fektetett a szociálpolitikára. Az iskolák, az egészségügy, a helyi tervezés és irányítás, az önkormányzati tevékenységek fejlesztése mind-mind a mezôgazdaságból felszabaduló munkaerố lekötését szolgálta. Ezzel megakadályozták Finnország egyes térségei teljes elnéptelenedését, sốt az 1980-as években az urbanizációval ellentétes folyamat indult meg. Nôni kezdtek azok a vidéki települések, amelyek fontos információs központként müködtek, és állandóan lassították azt a folyamatot, amelyet faluról a városba költözésnek nevezünk.

Ma a Finnországra jellemzõ magas (18\%-os) munkanélküliség szintén egy enyhe falura való visszaköltözést eredményezett. Minden tudatos politika és tervezés ellenére azonban a fố vándorlási mozgás Finnországban is, mint mindenütt a világon, faluról a városba irányul. Az új kihívás, az Európai Unióhoz való csatlakozás felgyorsíthatja a falvak elhagyását. Ennek elkerülése érdekében a szerzôk üj regionális stratégiai gondolkodás kidolgozásáról elmélkednek. Alapvetô kiindulási pontjuk, hogy az Európai Unió országai nem rurális térségek, és ezért az Európai
Uniónak nincs megfelelố vidékpolitikája. Itt kell kiemelni, hogy a szerzôk célja e könyv megírásával éppen az volt, hogy az Európai Uniót arra bírják rá, hogy dolgozzanak ki egy közös vidékpolitikát, és abban a finn érdekeket a legmesszebbmenôkig vegyék figyelembe.

A könyv szerzôi, akárcsak a finn kutatók többsége, azt a stratégiát követik, hogy Finnországot nem egyedüi, hanem a másik két északi országgal, Norvégiával és Svédországgal együtt taglalják. A Skandináv országok két nagy régióra oszthatók: az északira és a délire. $\mathrm{Az} 1 \mathrm{~km}^{2}$-re esô lakosok száma Észak-Skandináviában 4,2, Dél-Skandináviában 27,6, a 12 EUországban pedig 144,3 fố. A szerzốk a népsürüségen kívül még ÉszakSkandinávia egyéb sajátosságait is kiemelik. Az adatokból egyértelmũen látszik, hogy a nemzeti határokon belül Észak-Skandinávia agrártérségnek számít.

A jóléti társadalmaknak köszönhetôen, az 1970-es évektôl kezdődõen azonban az említet országokban olyan regionális politikát tudtak folytałni, amely e térségek felzárkóztatásához vezetett. Tehát a Skandináv országokban a fejlettség szempontjából nincsenek nagy regionális különbségek, az agrártérségek nem elmaradott területek, ezért ôk a meglévổ EU támogatási rendszerben nem sok jóban reménykedhetnek.

Szeretnék a finnek ,elhitetni" az Európai Unióval, hogy a gyéren lakott térségek számára is ki kellene találni valamilyen támogatási rendszert. Azzal érvelnek, hogy nekik ezek a vidékek épp olyan problémákat jelenthetnek, mint az elmaradott térségek a meglévô EU-tagországok számára. Az Észak-Skandináv térséget a 
szerzök perifériának nevezik, ahol országaik a múltban olyan regionális politikát folytattak, hogy az oktatás, a kommunikáció és szállítás modernizálása terén nagy befektetéseket igényelt, amit a jövốben is folytatniuk kell, ha nem akarnak a fejlôdésben lemaradni. Tehát Észak-Skandinávia periféria, de nem elmaradott vallják a szerző́k -, és ebben különbözik e térség Európa más perifériáitól, amelyekre az jellemzó, hogy elmaradottak.

A szerzök hangsúlyozzák, hogy ÉszakSkandinávia több kihívással fog találkozni az EU-hoz való csatlakozás folytán, mint a közép-európai régiók. Közép-európai régió alatt ởk nem térségünket, hanem az EU gazdaságilag fejlett országait értik. Ezekben az országokban piacorientált mezôgazdaság van, amelyekkel a finn és a norvég periférián élố farmgazdaságok képtelenek lesznek versenyezni.

Finnország függetlenségének megszerzése után a mezôgazdaságból és az erdôgazdaságból a lakosság több mint kétharmada, a második világháború után meg több mint 50\%-a élt. Mára ez az arány 9\%-ra csökkent (ami még mindig duplája az EU országokénak), de Finnország keleti és északi részén a mezôgazdasågból élôk aránya ennél jóval magasabb. Ráadásul az ország keleti és északi részén a farmerek jövedelmének jelentős hányada az erdôgazdálkodásból származik, ahol még alacsonyabb a jövedelem, mint a mezốgazdaságban. Egyébként ma 200000 olyan finn farmert tartanak nyilván, akiknek egy hektárnál nagyobb mũvelhetô földterülete van, de ezek közül csak 120000 számít aktív farmernek. Aktív farmernek az számít, aki maga múveli a földet. Fôleg északon és keleten sok az inaktív farmer. Az átlag finn farm 13 hektár mũvelhetô földdel és 35 hektár erdôvel rendelkezik.

A könyvböl kiderül, hogy a második világháború utáni finn mezôgazdaság a fejlổdését elsôsorban a hazai termékek támogatottságának köszönheti. (Európában a támogatottság szempontjából a finn mezögazdaság a harmadik helyen van.)

A következô aggály, amit a szerzốk felvetnek, az a vámtarifára vonatkozik. A finnek a külföldi mezõgazdasági áruk vámolásánál mennyiségi korlátot alkalmaznak, az EU-ban pedig nincs mennyiségi korlát, hanem minden egyes Közösségen kívüli országból behozott agrártermékre vámot vetnek ki. A finnek, ha automatikusan átvennék az EK vámszabályait, akkor a mostanihoz képest kedvezổtlenebb helyzetbe kerülnének.

Az elônyökrốl szólva azzal számolnak, hogy a tejtermékek és a borjúhús terén versenyképesek lesznek, ezért az ilyen áruféleségek termelésére átálló farmerek támogatását ajánlják, mégpedig a gabonatermelö - tegyük hozzá - délnyugati térségekben élô farmerek számára. Azok számára, akik 20-30 évvel ezelött éppen ezzel az ágazattal hagytak fel, és akik most nem a leggyérebben lakott térségekben élnek.

A másik ágazat, amelynek felfuttatását a kutatók nagy elốszeretettel ajánlják, az a biotermelés. Ugyanakkor felteszik a kérdést, hogy vajon hány farmer lesz képes a „,visszalépésre", azaz a biotermeléssel való foglalkozásra, amely több munkát igényel, és vajon milyen ára lesz a biotermékeknek?

$\mathrm{Az}$ egyik fô problémát abban jelölik meg, hogy Finnország északi és keleti részén, továbbá egész Észak-Skandináviában 
az emberek gondolkodása és erkölcsi normái fớleg városiasak. A városiak hatékonysági normái pedig arra irányulnak, hogy minél jobban kiaknázzák a természeti és a helyi eröforrásokat. E szemlélet megváltoztatását a szocializáció révén kívánják elérni. A szerzők is tudják, hogy tisztán a biotermelésböl nem lehet megélni. A biotermelést a problémák megoldásának egyik útjaként csak olyan értelemben tartják lehetségesnek, ha azt nem gazdasági oldalról nézik, hanem az önbizalom és a valamiféle finn ,,magad uram, ha nincs szolgád" szellemiség megjelenéseként fogják fel.

A szerzốk a könyv jelentôs részét a finn vidékpolitika körvonalazásának szentelik. Ambiciózus célkitũzéseket fogalmaznak meg, mint például azt, hogy 2010-ben ugyanannyian kell, hogy éljenek a rurális térségekben, mint 1990-ben. Ez a finnek egynegyedét jelenti. Rurális térség alatt ôk a ritkán lakott térségeket értik, amelyek olyan falvakból állnak, ahol a lakosság 500 fố alatt van. A finn vidékpolitika fô célja a rurális térségek újjáélesztése azáltal, hogy javítják az életfeltételeket, a szolgáltatásokat és vonzóvá teszik a vidéket mind a lakhatás, mind a vállal- kozás, mind pedig a szabadidố eltöltése szempontjából. A finn nemzeti vidékpolitika a vidéket három kategóriába sorolja: a városkörnyéki, az agrár- és az elszigetelt vidékek. A fejlódés szempontjából a városkörnyéki falvak vannak a legjobb helyzetben, mert lakóik munkát találhatnak a városban és agrártermékeiknek jó piaca van a közelben. Ezek és a jó közlekedési útvonalak mentén lévố falvak fejlôdéséhez nem fér kétség. Az agrárvidékeknél a további diverzifikáció lehetôségét kínálják a kutatók. A legnagyobb problémát az elszigetelt vidékek jelentik. Eddig is ezek élvezték a legjelentôsebb támogatást, nyilvánvaló, ezután is ezek fogják a legtöbb központi és regionális támogatást megszerezni, és még ennek ellenére is elôfordulhat, hogy Finnországban az EU-hoz való csatlakozás után az ilyen térségek teljesen elnéptelenednek. A szerzôk nem írják le, de tudott tény, a finnek attól tartanak, hogy az esetleg elnéptelenedõ területekre idegenek települnek be. Ennek még a gondolata is - érzelmi szempontból - katasztrófaként jelenik meg elổttük. 